\title{
Engineering and development in Brazil, challenges and prospects: a new perspective on the topic
}

\author{
Luís Grochocki
}

CAPES, Stanford University, Stanford, California, USA

Jorge Guimarães

Brazilian Research and Industrial Innovation Company, Brasilia, Brazil

\author{
Alvaro Prata \\ Department of Mechanical Engineering, Federal University of Santa Catarina, \\ Florianópolis, Brazil, and \\ João Oliveira \\ Department of Production Engineering, University of São Paulo, São Paulo, Brazil
}

Engineering

and

development

Received 2 September 2017 Accepted 15 January 2018

\begin{abstract}
Purpose - Engineering is a powerful instrument for promoting the social and economic development of nations. Its enhancement is a strategic element to accelerate Brazil's progress. This paper aims to present a new perspective on the topic of "Engineering and Development in Brazil, Challenges and Prospects" (Guimarães et al., 2007). Its goal is to discuss the need for restructuring the Brazilian system for research, development and innovation (RD\&I) and the training of human resources in engineering in the country.

Design/methodology/approach - This article is designed to discuss the relations between the performance of the industrial sector and the maturation of engineering in Brazil by looking at the national scientific production in the area in comparison to the world production and to countries (South Korea and The Netherlands). Finally, in terms of training human resources, the Brazilian study abroad program Science without Borders program is discussed in the article as an important tool for the qualification of engineering students in Brazil.

Findings - A few of the main findings in this research are as follows: despite being among the top 20 countries in scientific production in Engineering, Brazil still lacks turning this scientific-technological knowledge into products and patents; Brazilian universities and research institutes must build interorganizational collaborations with the industrial sector to increase innovation in the field of engineering; The distribution of the investment in RD\&I in engineering must be strategically distributed among its various fields, taking into account national strategies and the technological interrelations between them. The article concludes that engineering is a powerful instrument for promoting a country's social development while offering indications about Brazilian strategic orientation in the development of engineering.

Originality/value - Despite already being well known that engineering is a powerful instrument for promoting a country's social development, this article innovates by associating academic scientific production in engineering to other variables related to economic development, such as gross domestic product, human development index, industrial and manufactured production and the filing of patents. It comes at an

(C) Luís Grochocki, Jorge Guimarães, Alvaro Prata and João Oliveira. Published in the Innovation \& Management Review. Published by Emerald Publishing Limited. This article is published under the Creative Commons Attribution (CC BY 4.0) licence. Anyone may reproduce, distribute, translate and create derivative works of this article (for both commercial and non-commercial purposes), subject to full attribution to the original publication and authors. The full terms of this licence may be seen at http://creativecommons.org/licences/by/4.0/legalcode
\end{abstract}
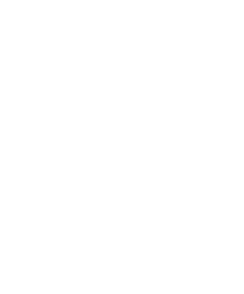
INMR 15,1

important moment when the Brazilian Government is discussing new strategies to increase social and economic development in the country while controlling for the investment in RD\&I. Therefore, it is the right moment to discuss national policies in science, technology and innovation, especially in the area of engineering.

Keywords Brazil, Engineering, Socioeconomic development, Productive systems, Industrial development

Paper type Research paper

\section{Introduction}

Since 2005, Brazil has been ranked among the ten largest economies in the world, currently occupying eighth place in terms of global gross domestic product (GDP) (Global R\&D Funding Forecast, 2017). Despite the recognized, cyclical pace of the Brazilian economy in recent decades, there has been a certain period of monetary stabilization and an adoption of social public policies aimed at income redistribution. Thus, the fall in the unemployment rate, combined with a favorable external environment and a strengthened internal market, guaranteed a cycle of economic growth and social inclusion during this period (Brazil, 2012). However, recent studies demonstrate that the country's productivity did not follow the economic growth of this period, particularly with regard to the industry. Unlike events in the previous decade, between 2001 and 2009, there was a greater disparity in relation to GDP per capita versus growth in productivity. In other words, Brazilian GDP per capita evolved significantly in the above-mentioned decade, while productivity remained relatively stable. This gap emerged mainly because of the strong correlation between GDP growth and the increase in the workforce and purchasing power, though with less significant contributions from productivity (De Negri and Cavalcante, 2013). A study by the Boston Consulting Group concluded that over the past decade, the gain in productivity for GDP growth in Brazil was only 26 per cent, while the remaining 74 per cent was attributed to the fall in unemployment - a rather different scenario from that of China and India, where contributions from productivity have reached 93 and 82 per cent, respectively. Finally, it is important to highlight that the modest growth in Brazilian productivity occurred, chiefly, in the extractive industry and in farming and livestock, sectors that concern directly natural resources and entail relatively low added value (Ukon et al, 2013). Given that the unemployment rate fell considerably in this most positive, above-mentioned period for the Brazilian economy, it is impossible to rely only on the significant increase in the economically active population to increase GDP. For Brazil to resume the virtuous cycle of economic growth and social development, there needs to be an upturn in productivity rates and innovation capacity, particularly through the qualification of the workforce[1] and integration between the research and industrial sectors.

At present, the world is intensely experiencing the knowledge economy in which the main production inputs are no longer physical assets but rather intellectual work. Hence, the effort to create new products and new technologies has acquired a growing value in the contemporary world. The current challenge, even for developed countries, is therefore to master cutting-edge technology in the industrial sectors, generating jobs of a higher intellectual level. Generally, these jobs offer greater social benefits, on account of the chance to create new business opportunities, as well as the increased wealth generated and the resulting growth in GDP per capita and, above all, the inclusion of young people in demanding processes of creative innovation. Nevertheless, technological innovations, the development of national infrastructure and the emergence and establishment of small- and medium-sized industries and businesses require the presence of contingents of well-qualified 
engineers. They should be the designers, technical managers and operators, constituting the largest portion of the industrial sector's skilled workforce. A clear demonstration is the progress shown in recent decades by several previously technologically emerging countries - such as India, Spain, China, South Korea, Taiwan and Singapore - of which the development basis has been the emphasis on industrial processes requiring qualified groups of engineers. Importantly, all these countries are currently direct competitors of Brazil, and there is a comparative disadvantage in relation to them concerning the exportation of manufactured products. Thus, it is concluded that engineering is a powerful instrument for promoting a country's social development. In the case of Brazil, which possesses innumerable comparative advantages and immense natural richness, at the present stage of development, there is clearly a great need for a body of well-trained engineers, with consolidated skills and willing to be innovators and entrepreneurs.

\section{Research and development in universities and research centers in Brazil}

A positive aspect of this challenge concerns the academic field. In this regard, Brazil has evidently achieved an extraordinary performance over the past two decades and since 2008 has occupied 13th place for scientific production at the global level, overtaking countries with a far greater tradition in research and training of human resources, such as The Netherlands, Switzerland, Sweden, Belgium, Denmark and Israel. Endeavoring to occupy the tenth position in the global science rankings by 2020, Brazil is seeking to place itself among the top ten countries with the greatest potential to produce new knowledge, which would be more in line with its position in the global GDP rankings and with the correlation observed in the case of more developed countries in comparing GDP vs scientific production. In the past 30 years, Brazil has enhanced significantly its investment in science, technology and innovation (ST\&I)[2], investing 1.2 per cent of GDP in 2013. Nevertheless, in international comparisons, Brazil is still behind many countries regarding the number of scientists and engineers, the percentage of GDP investment in ST\&I and, consequently, in the human development index (HDI), as shown in Table I. In this context, it seems important to note that there is apparently a certain confluence between a proportion of at least 1.6 per cent of GDP in R\&D and the existence of a minimum level of around 3,000 scientists and engineers per 1 million inhabitants in allowing a country to occupy a more prominent position in terms of the social and economic development of nations.

In fact, the significant results of Brazilian science come from the fact that the country's outstanding scientific development occurs at universities, particularly on graduate courses, which generate thousands of dissertations and theses per year (in 2015, there were around 55,000 master's dissertations and $18,000 \mathrm{PhD}$ theses), certainly adding to Brazil's internationally acknowledged scientific production[3].

Although Brazil has attained these results in science, the country's performance is poor with regard to the registration of patents that could entail applied industrial technology. For various reasons, including the inexperience of the university system, the interaction between universities and companies has lagged behind and is still evolving slowly in Brazil. Hence, and also because of a lack of effective industrial demand, the university community has directed research to emphasize on academic production, that is, in a direction out of tune with that experienced by the industrial community in developed countries.

Perhaps for the same reasons, there is little interaction between research groups and centers in collaboration and the sharing across networks of knowledge generated, to be applied at companies. In addition, basic industrial technology developed in Brazil often fails to result in productivity gains because of the existing disparities disparity between the companies' objectives and those of research centers. Ultimately, national companies invest 


\begin{tabular}{|c|c|c|c|c|c|c|}
\hline $\begin{array}{l}\text { INMR } \\
15,1\end{array}$ & $\begin{array}{r}\text { Co } \\
\text { World ranking }\end{array}$ & $\begin{array}{l}\text { untries } \\
\text { Country }\end{array}$ & $\begin{array}{l}\text { GDP in } \\
\text { S\&T }(\%)\end{array}$ & $\begin{array}{l}\text { Scientists and engineers per } \\
\text { one million inhabitants }{ }^{\mathrm{a}}\end{array}$ & Index & $\begin{array}{l}\text { HDI } \\
\text { World ranking }\end{array}$ \\
\hline \multirow{5}{*}{44} & 1 & Israel & 4.2 & 8.282 & 0.888 & 19 \\
\hline & 2 & South Korea & 4.2 & 6.457 & 0.891 & 15 \\
\hline & 3 & Japan & 3.5 & 5.201 & 0.890 & 17 \\
\hline & 4 & Finland & 3.3 & 7.188 & 0.879 & 24 \\
\hline & 5 & Sweden & 3.3 & 6.473 & 0.898 & 12 \\
\hline \multirow{26}{*}{$\begin{array}{l}\text { Table I. } \\
\text { Position of Brazil in } \\
\text { the rankings for } \\
\text { countries that invest } \\
\text { the highest } \\
\text { percentages of GDP } \\
\text { in S\&T }\end{array}$} & 6 & Denmark & 3.1 & 7.265 & 0.900 & 10 \\
\hline & 7 & Switzerland & 3.0 & 4.481 & 0.917 & 3 \\
\hline & 8 & Germany & 2.9 & 4.472 & 0.911 & 6 \\
\hline & 9 & Austria & 2.8 & 4.704 & 0.881 & 21 \\
\hline & 10 & USA & 2.8 & 4.019 & 0.914 & 5 \\
\hline & 11 & Slovenia & 2.6 & 4.217 & 0.874 & 25 \\
\hline & 12 & Taiwan & 2.4 & NR & 0.719 & 91 \\
\hline & 13 & Australia & 2.3 & 4.335 & 0.933 & 2 \\
\hline & 14 & Belgium & 2.3 & 4.003 & 0.881 & 21 \\
\hline & 15 & France & 2.2 & 4.153 & 0.884 & 20 \\
\hline & 16 & Singapore & 2.0 & 6.442 & 0.901 & 9 \\
\hline & 17 & The Netherlands & 2.0 & 4.303 & 0.915 & 4 \\
\hline & 18 & China & 2.0 & 1.089 & 0.719 & 91 \\
\hline & 19 & Czech Republic & 1.9 & 3.251 & 0.861 & 28 \\
\hline & 20 & Estonia & 1.7 & 3.339 & 0.840 & 33 \\
\hline & 21 & Canada & 1.6 & 4.490 & 0.902 & 8 \\
\hline & 22 & England & 1.6 & 4.055 & 0.892 & 14 \\
\hline & 23 & Scotland & 1.6 & 4.055 & 0.892 & 14 \\
\hline & 24 & Ireland & 1.6 & 3.371 & 0.899 & 11 \\
\hline & 25 & Hungary & 1.4 & 2.523 & 0.818 & 43 \\
\hline & 26 & Portugal & 1.4 & 4.142 & 0.822 & 41 \\
\hline & 27 & Italy & 1.3 & 1.974 & 0.872 & 26 \\
\hline & 28 & Spain & 1.2 & 2.653 & 0.869 & 27 \\
\hline & 29 & Brazil & 1.2 & 698 & 0.744 & 79 \\
\hline & 30 & Russia & 1.1 & 3.073 & 0.778 & 57 \\
\hline & \multicolumn{6}{|c|}{$\begin{array}{l}\text { Note: anumber of scientists and engineers per } 1 \text { million inhabitants and respective HDIs } \\
\text { Source: Zanotto and Guimarães (2016) }\end{array}$} \\
\hline
\end{tabular}

little in R\&D, and the number of scientists and researchers that operate in the core activities of national companies is still low compared with Germany, Canada, China, South Korea, the USA, France, Japan and Russia, countries with swifter technological development processes (Figure 1).

With respect to public Brazilian research institutes, it is also clear that general planning does not reflect a priority to operate in $\mathrm{R} \& \mathrm{D}$ at the frontiers of knowledge linked to business demands. The American model needs to be highlighted, where national laboratories receive from the respective supervising departments and research development missions that are already in line with companies, resulting in technological products that are of national interest and very often procured by the government itself. This culture of integrated research programs is almost non-existent in Brazil. At best, fields of activity are prioritized, which normally results in a body of quality knowledge, though it is disjointed and unaligned with companies.

Nevertheless, there have been several success stories in Brazilian engineering. Good examples include: 
- the development of technology for oil extraction in deep waters, with intense participation from the Alberto Luiz Coimbra Institute for Graduate Studies and Research in Engineering;

- the aeronautics industry being associated with the CTA/ITA complex (Center of Advanced Technology/Technological Institute of Aeronautics);

- the wide support for developing engineering through the REENG/RECOPE program (Cooperative Research Networks/Re-engineering of Engineering Teaching);

Engineering and development

- the development of methods and tools that have made Brazilian banking automation one of the best in the world and the joint research projects between Brazilian and German groups in manufacturing engineering via the Bragecrim program (Brazil Germany Collaborative Research Initiative on Manufacturing Technology), with diverse impacts in industry.

Despite the structural weaknesses, the production of patents filed by resident institutions increased in Brazil between 1999 and 2013, allowing the country to occupy its current 25th place globally in terms of patents filed. However, a significant proportion of the patents filed originate from universities and research centers. For instance, among the ten main institutions that filed patents in Brazil in 2015, three were universities, with UFMG and UNESP occupying the fifth and sixth places, respectively, on a level footing with companies such as Braskem and Petrobrás (Table II).

In this regard, it is worth mentioning the excellent study by Narim et al. (1997), demonstrating that in more technologically competitive countries (USA, Japan, Germany, Canada and others), the patents registered are largely ratified on account of the scientific knowledge generated in the country. In the case of the USA, 73 per cent of industrial patents are scientifically substantiated by the theoretical and technical content obtained from the scientific publications produced by the academic sector based on the studies financed through public funds from American development agencies (Narim et al., 1997). In the case of Brazil, using a comparative approach, it has been demonstrated (De Meis et al., 2007) that there is an intimate and positive correlation between scientific production and the number of patents registered, both in Brazil and abroad. In South Korea's case, this indicator is correlated with the volume of funds invested in RD\&I by companies. Thus, as Brazil has

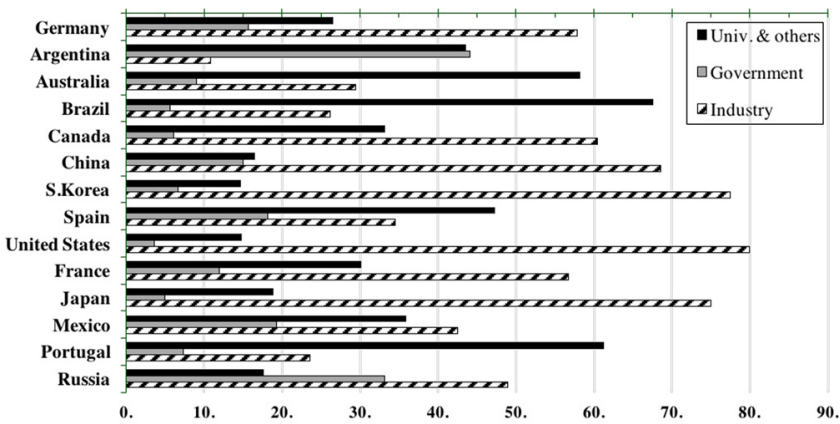

Source: MSTI, Bernardo, Sérgio, Seminário Patentes INPI-FEA/ UNICAMP, www.slideshare.net/camilobt/seminario-patentesinpifeaunicamp2012

Figure 1. Participation (per cent) of scientists operating at universities, in government and industry in Brazil and various countries 
INMR

15,1

46

such a recent ST\&I system, along with a high scientific level, stimulus still needs to be provided to transform accumulated knowledge (ST\&I) into productive activity (RD\&I), a clear appeal to the inherently innovative spirit that typifies a modern and competitive industrial sector.

Given what has been discussed so far, efforts to enhance the competitiveness of Brazilian companies must be conceived in a specific manner. Such efforts involve taking full advantage of the ST\&I potential in place at Brazilian universities and research centers. They must take account of the quest to master innovating technologies and the creation of a developed business environment, composed of large manufacturing companies, surrounded by small high-tech companies, capable of creating new products and selling services that add great value. A healthy relationship with academic institutions must include the provision of quality education for the professionals required for the enterprises and the development of cutting-edge technology. Engineering certainly plays a crucial role in this context; its consolidation and structuring must observe the principles that enhance business development, which include major integration with the business sector and consistent distribution among the fields of operation.

\section{RD\&I in companies in Brazil}

It is well known that Brazil carries out little R\&D in the industrial sector, compared with more developed countries. The understanding many businessmen have of what RD\&I represents is closely linked to foreign technological dependence. A survey conducted by the National Confederation of Industry ( $\mathrm{NCI}$ ) shows that in national companies, investment in RD\&I amounts to non-specific research activities such as staff training, spending on products and purchasing machines. Importantly, the concept of human resources that guided the responses of the businessmen in the NCI survey is restricted to the training of machine operators and sales staff, therefore falling short of what is discussed in this article.

A study by the Conference Board demonstrated that in 2013, the mean productivity of employees at Brazilian companies was US $\$ 10.8 / \mathrm{h}$ of work, while Chile (US\$20.8), Mexico (US $\$ 16.8$ ) and Argentina (US\$13.9) had far higher means. Furthermore, in recent years, the growth in the Brazilian productivity rate was only 0.8 per cent, while China hit 7.1 per cent[4]. For this rate to improve, investment in education, technology and innovation will be necessary.

\begin{tabular}{lcc}
\hline Filing party & Total & World ranking \\
\hline WHIRLPOOL S.A. & 21 & 993 \\
MAHLE METAL LEVE S.A. & 18 & 1,153 \\
BRASKEM S.A. & 16 & 1,292 \\
PETROBRAS & 14 & 1,466 \\
UFMG & 10 & 1,980 \\
UNESP & 8 & 2,415 \\
SLIM DRILLING SERVIÇOS DE PERFURAÇÃO S.A. & 7 & 2,702 \\
PUCRS & 6 & 3,070 \\
WEG EQUIPAMENTOS ELETRÔNICOS S.A. & 6 & 3,070 \\
IPT-SP & 5 & 3,595 \\
Total Brazil & 547 & 25 \\
Source: World Intellectual Property Organization (2015) & & \\
\hline
\end{tabular}

Table II.

Ten main institutions holding patent registrations, with Brazilian priority (2015)

Source: World Intellectual Property Organization (2015) 
Researchers who operate in Brazil in core activities linked to R\&D are mainly at universities and research institutes, as illustrated in Figure 1. This scenario contrasts with that of other countries, where most researchers are concentrated in industries. In absolute terms, the number of scientists and engineers operating at Brazilian universities is greater those operating in South Korea; hence, what Brazil lacks is a planning policy and system at institutions to include collaboration between universities and companies in research, with the resulting establishment of researchers in the industrial sector. Two basic needs can be identified in the sector of qualified human resources for R\&D in Brazil. The first is the and development development of skills to perform at RD\&I centers in industries, and the second is the training of professionals to operate in the growing business system. For the first demand, greater integration between companies and universities is needed, and the lynchpin is the development of integrated projects that serve the interests of both sectors. Collaboration with the business sector means that the academic sectors understand business demands regarding the generation of knowledge. A successful example of such cooperation is provided by Powell et al. (2005) when analyzing interorganizational cooperation in the life sciences in the USA. According to the authors, universities played a major role in building the new field of biotechnology, allowing companies to convert basic science to new products. Building similar collaborations would also be very important in engineering and must be sought by Brazilian universities and research institutions. For the second demand, it is necessary to have a balanced distribution of training across the various fields in national engineering.

To meet the need to improve the planning of institutions in areas that have more potential for interaction with companies, in 2013, the then Ministry of Science, Technology and Innovation signed a contract with EMBRAPII - Brazilian Industrial Research and Innovation Enterprise. The contract, of which the Ministry of Education is also a supporter, provides non-refundable financial resources for a system of selected institutions (EMBRAPII Units) to carry out clear research programs, with well-defined areas of expertise, integrated with companies. The EMBRAPII system has yielded good results, and in just over two years, it has accredited 34 research groups operating in RD\&I and managed to make available over $\mathrm{R} \$ 330 \mathrm{~m}$ across 240 projects stemming from companies' demands.

\section{The challenge for small- and medium-sized companies}

The demands of the manufacturing and equipment industries (agriculture, automobile, electronics, etc.) highlight the critical position of current industrial development. There is a clear, growing need for greater participation and performance from small- and mediumsized companies. Nonetheless, there is a lack of scientific-technological knowledge, which, in turn, is intimately linked to the low supply of well-trained engineers in the country.

\section{Demands for a system of graduate studies and research in engineering}

Research and graduate qualifications have been stimulated in unequivocal and monolithic fashion in Brazil. For there to be an enhancement in quality and quantity in engineering, it is necessary to comprehend the role of each of its subfields, taking into account the characteristics and peculiarities of each sector. In engineering, two elements need to be addressed:

(1) the adoption of a research management model that follows and meets the business demands of national engineering; and

(2) the establishment of a balance between the different fields of engineering so that the development of one supports the development of others. 
INMR

15,1

48
Figure 2.

Model to support the business sector in Brazil
One example of a management model that brings academia closer to the industrial sector is outlined in Figure 2. The lower part of the figure features the basic elements for a company to be competitive: strategy, product development, logistics and production management and manufacturing technology. All these elements must be supported by computerized systems and tools. The upper part of the figure outlines the research and graduate studies fields that must be developed in academia to support and maintain the business sector. This development must occur based on business demands. For their part, the respective research and graduate studies fields still need to be integrated and catered for by the industrial sector. The listed fields take account of the demands of companies that operate in different segments and can vary depending on the type of company and market sector.

The second element to consider in stimulating research is higher graduate qualifications in engineering and establishing a balance between the different concentrations within engineering. For instance, the mechanics industry depends on the electronics industry for the development of its control and monitoring systems, and thus, it is impossible to have a strong and competitive mechanical industry sector without strong electronic engineering. Such a distribution in the competence profile and quantity of human and research resources in the different engineering fields can be established based on a global reference. This distribution is outlined and discussed below. Brazil needs to observe this standard to plan its engineering development strategy. Figure 3 displays the model of Figure 2 with an expectation of participation from engineers and other sister areas. Notably, there is a great demand for high-level planning activities that must be developed by production engineers in various sectors. The role of these professionals needs to be studied thoroughly so as to offer students training in the essential modern tools for successful business development.

\section{Economic growth and the development of engineering in Brazil and the world}

Few countries are protagonists of global scientific production in engineering in indexed journals. Approximately 70 per cent of what is published worldwide in engineering can be attributed to ten countries: China (including Hong Kong, Macau and Taiwan), the USA, the UK, South Korea, Japan, France, Germany, India and Iran. They are also leaders in global technological production. From this group, it is worth highlighting China, India, Canada and South Korea, competitors for Brazil in several commercial sectors. Brazil has gone down in

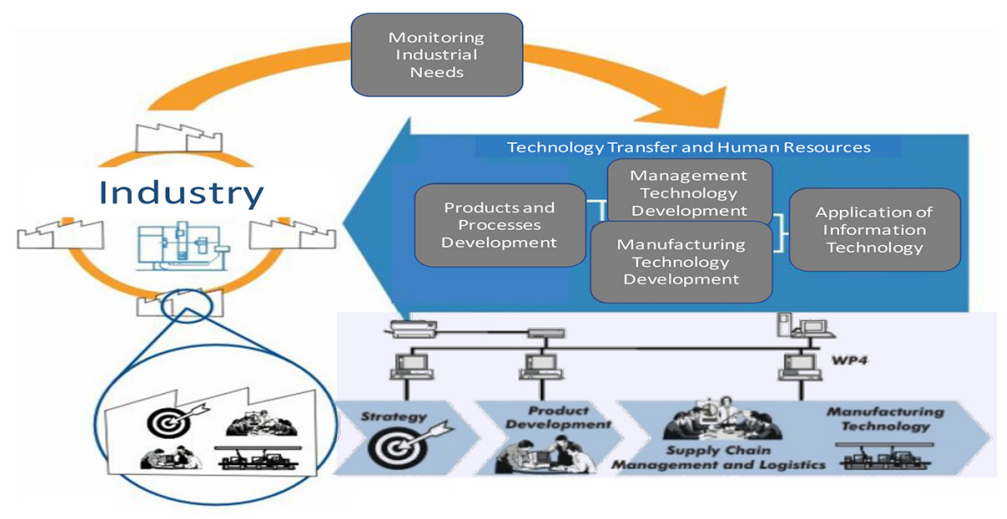

Notes: Factory of the Millennium Institute (FMI) ref., MSTI proposal 


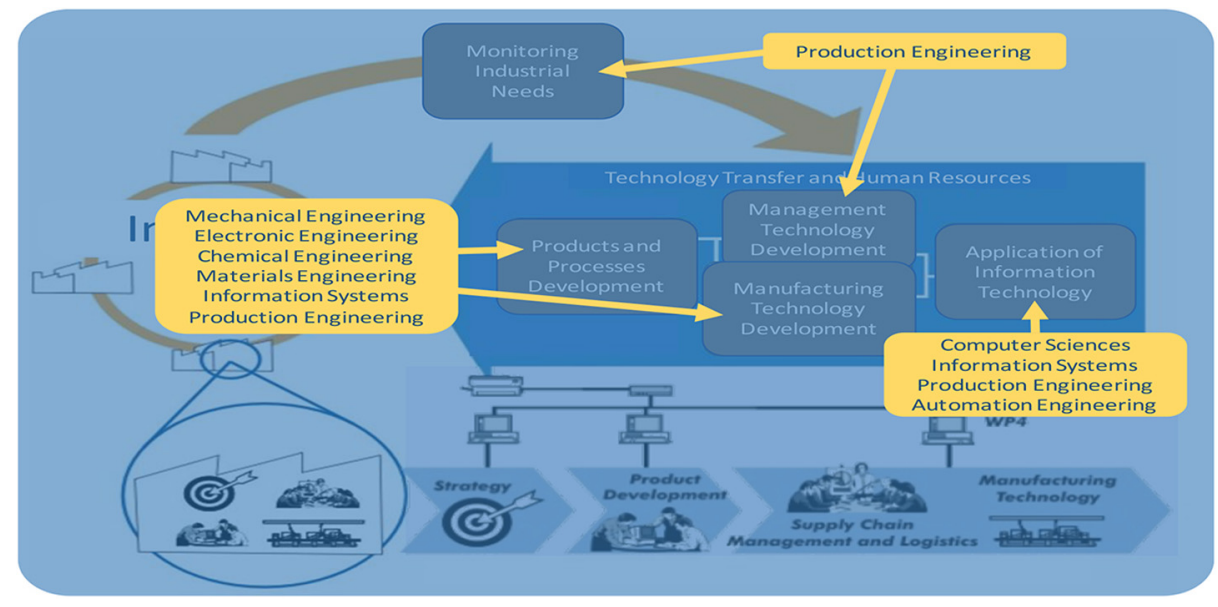

Engineering and development

the engineering rankings and currently occupies 18th place, accounting for around 1.33 per cent of global scientific production (around 8,390 articles between 2010 and 2014). The charts in Figure 4 outline global participation in engineering in the main countries. One point to note is that Brazil is the only Latin American country to feature among the 20 most competitive countries in engineering, having been recognized for its strong engineering.

Furthermore, there is a direct correlation between engineering production and the economic indicators of each country, as illustrated in Table III. An analysis of this table backs the thesis outlined in this article that stress the importance of engineering to a country's development. It is apparent that with the exception of Brazil and Mexico, the 15 largest economies in the world are those that publish the most in engineering. Another curious element is the relationship between scientific production in engineering and the GDP of emerging Asian countries such as South Korea, Singapore and Malaysia. The ranking of these countries as producers of engineering knowledge is higher than for their respective GDPs. Notably Singapore, the 19th most productive country, but 36th in terms of GDP. The concern for engineering in these countries explains and predicts their economic growth[5].

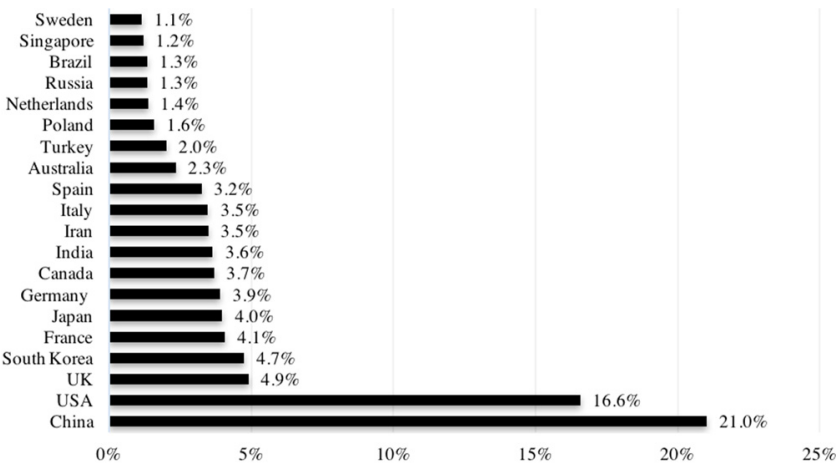

Figure 4.

Top 20 global participation per country[7] in qualified publications in engineering (2010-2014)

Participation of engineers-researchers in the model of Figure 2

Source: InCitesTM database, Thomson Reuters - 2015 


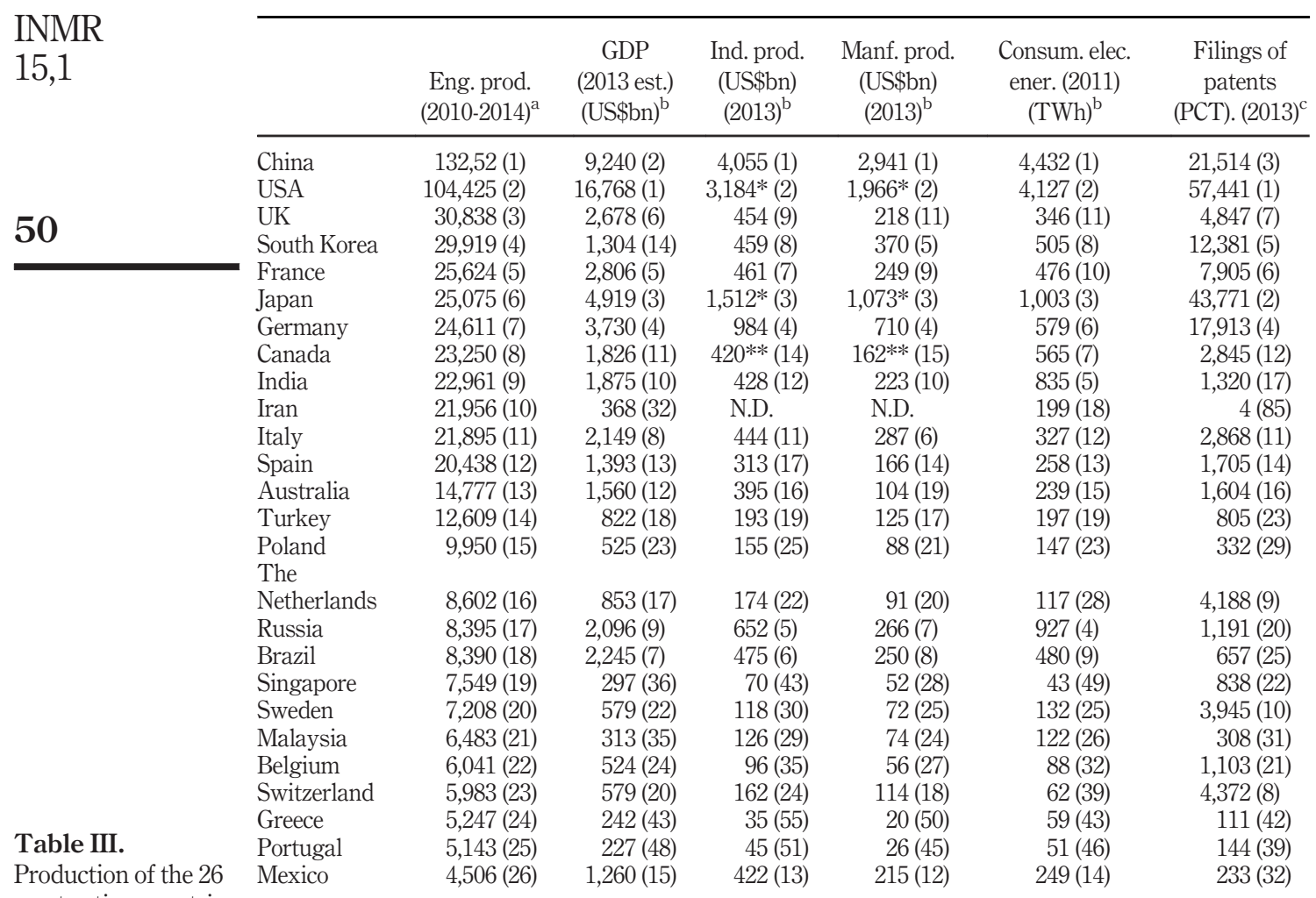
most active countries in engineering and their economic indicators

Notes: The global ranking of each country for the indicator appears in parentheses; ${ }^{a}$ In Cites TM database, Thomson Reuters (2015); ${ }^{\mathrm{B}}$ The World Bank Development Indicators (WDI); ${ }^{\circ}$ World Intellectual Property Organization (International filings via WIPO Administered Treaties-PCT); * Data relative to 2012; **'Data relative to 2010

In addition, when analyzing industrial production and manufactured products (fourth and fifth columns of Table III) respectively, the correlation with scientific production in engineering appears to be even stronger. An aspect to be highlighted is that almost 44 per cent of China's GDP and 40 per cent of Malaysia's GDP emanates from the industrial sector, representing the highest percentages among the countries analyzed[6].

The sixth column of the table outlines the countries' electrical energy consumption. Of the 26 countries that produce the most articles in engineering, 17 are among those that consume the most electrical energy.

Finally, the last column outlines the number of international filings of patents per country. It is worth highlighting the excellent performance of The Netherlands with regard to this criterion, with a significantly higher patent ranking than for the other indicators. Other outstanding nations include Switzerland (8th), Sweden (10th), Finland (13th), Israel (15th), Denmark (18th), Austria (19th) and Belgium (21st), countries that demonstrate more positive results in generating patents compared with others that are better qualified in the production of engineering knowledge, along with industrial and manufacturing production. 
From this table, it is clear that smaller Asian countries (South Korea, Singapore and Malaysia) are outliers in terms of qualified production in engineering, relative to their other economic indicators. On the other hand, the engineering production of Brazil and Mexico is inferior compared to the potential that their economic indicators display.

The following discussion explores the distribution of publications in engineering in the world and Brazil by field of knowledge. As presented in Figure 5, the three largest fields (materials, computing and electronics) correspond to the engineering branches reflecting the most significant scientific production in Brazil (48.9 per cent) and the world (50.9 per cent), with the field of materials leading production both in Brazil (23.1 per cent) and the world (24.7 per cent). Such numbers verify information already available from other indicators, namely, that although it is in the field of materials that Brazil publishes the most, the country needs to improve its global participation in industry. This represents an inversion in relation to the seven countries mentioned above, in which technological performance (filing of patents) is greater than academic production.

With respect to publications, Brazilian chemical engineering, along with environmental/ energy engineering, is well placed, while the field of nanoscience and nanotechnology is lagging behind compared with the percentages observed at the global level.

Moreover, it is interesting to compare Brazilian production in various fields of engineering with production in said fields in South Korea and The Netherlands. This information is displayed in Figure 6. Similar to Brazil, in South Korea, the most productive field of engineering is materials, yet the differences are five times greater, in favor of the Asian country. Likewise, in the chemical and electronics fields, there is a threefold difference relative to Brazilian production. However, the greatest difference with regard to publications is in the field of nanoscience and nanotechnology, where South Korea produces eight times as much. The profile for participation in the production of new scientific knowledge in engineering fields in South Korea is unique to countries with high rates of industrial development, where the transformation industry and high technology sector demand advanced engineering. Compared with The Netherlands, Brazilian production is more balanced. Nevertheless, The Netherlands stands out, above all, in the fields of computing and aerospace, while Brazil enjoys an advantage in materials, chemicals, metals and mining,

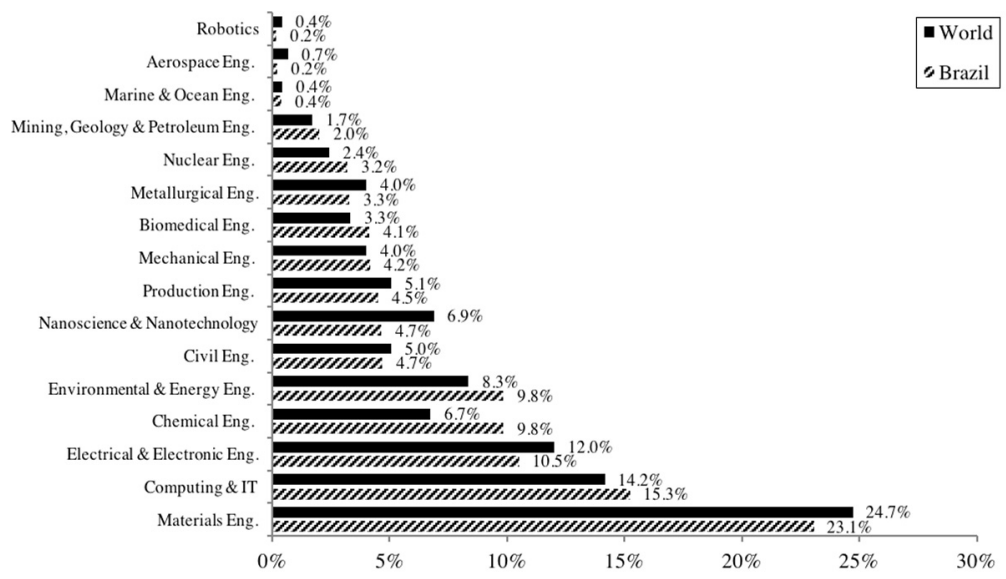

Figure 5. Global vs Brazilian distribution (by field) of qualified publications in engineering (2010-2014)

Source: InCitesTM database, Thomson Reuters - 2015 
INMR

15,1

Figure 6.

Comparison of qualified production in the various fields of engineering across Brazil, The

Netherlands and South Korea (2010-2014)
Figure 7.

Science without Borders scholarships - main fields considered (2011-2014) geology and petroleum. Thus, it may be beneficial to reflect on the model The Netherlands adopted to transform its production into an enhanced generation of patents relative to countries with similar engineering production, such as Brazil.

\section{The Science without Borders program}

Launched on July 26, 2011, the Science without Borders program became a strategic instrument for the Brazilian Government to invest in the qualified training of professionals from engineering and the other technological fields. The program sought the mobility of up to 101,000 students and researchers at foreign higher education institutions and laboratories with excellent reputations in teaching and research. In addition, the program aimed to attract young people and renowned researchers for them to develop research projects along with scientific and technological groups in Brazil. Figure 7 displays the distribution of scholarship holders across the fields of knowledge. Managed and implemented by Coordination for the Improvement of Higher Education Personnel (CAPES) and National

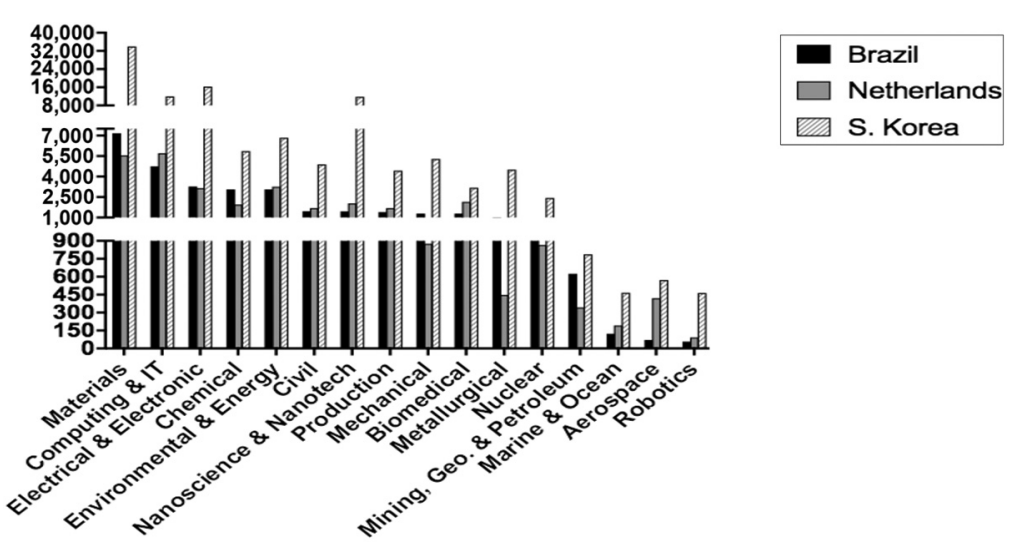

Source: InCitesTM database, Thomson Reuters - 2012
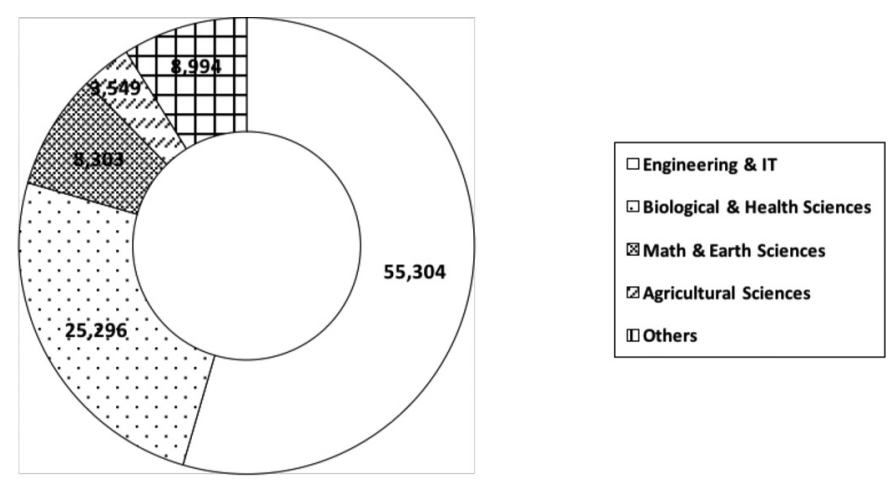

Source: CAPES/CNPq Database 
Council for Scientific and Technological Development (CNPq), the program was financed chiefly by public funds (75,000 scholarships). However, owing to its strategic character for the country's development, it triggered interest from the private sector. Hence, Brazilian companies (Petrobrás, Vale and Eletrobrás), foreign companies (Boeing, Shell, BG Group, Statoil, Petrogal) and directly concerned groups (FEBRABAN) offered to co-finance 26,000 additional scholarships, amounting to the target of 101,000.

With a focus on the academic qualification of engineers and the development of a researcher profile geared toward the demands of the private sector, the program brought innovation to the related fields involved. It complemented the activities of scholarship holders through the completion of professional internships abroad, impacting significantly their training. Seeking this objective, several cooperation agreements were signed between the funding agencies (CAPES and CNPq) and the partner companies on the program, which offered internship places at their head offices and subsidiaries across different countries. Within the participating companies, some are particularly noteworthy, including Boeing, Amgen, NASA, Hyunday, Samsung, Shell, Praxair, General Motors, Mitsui, Huawei and innumerable others. By offering internships abroad, companies have found within the Science without Borders program an opportunity to identify, during university, young, talented, highly-qualified individuals who can be harnessed as manpower at their subsidiaries upon returning to Brazil. Special attention should be paid to the 600 engineers sent on the professional master's programs (hands-on) at some of the best American institutions. As Figure 7 demonstrates, up until December 2014, the agencies met the program target and granted 101,446 scholarships, benefitting 55,304 students in engineering and related fields, which constitutes over 50 per cent of the entire program. Importantly, prior to Science without Borders being launched, CAPES was already showing signs of significant increases in the number of study-abroad scholarships granted to engineering students: from approximately 100 in 1998 to 1,000 in 2011 and 10,000 in 2013.

This contingent of benefitting scholarship holders is returning to Brazil with a distinguished profile. They possess technical knowledge of some of the best technologies available in their fields of practice, as well as a vision of how to apply theoretical study to address the global challenges currently being faced. With similar characteristics to the desired engineer profile, described by Richard K. Miller, President of the "Olin College of Engineering", one of the best engineering schools in the USA:

The role of the engineer we envision is that of "systems architect" of complex technical, social, economic, and political systems capable of addressing the global challenges we now face. Such engineers must be creative in conceiving, implementing, and managing the technologies that will shape our future. They must not only be applied scientists who are capable of predicting, creating, and developing the new science and technologies, but also organizational leaders and project managers capable of explaining complex socio-technical issues directly to the public, establishing trust through effective leadership, planning and implementation of integrated projects that deliver desired outcomes — not just products or devices — and do this on time and on budget. (. . .)

The educational implications of producing such engineers are substantial. Not only must these engineers continue to possess exceptional proficiency in STEM subjects, but they must also have substantial new abilities. In particular, they must have a broad awareness of complex global issues, a passion or strong motivation to make a positive difference in the world in the largest sense, and a "can-do" attitude that is characteristic of the best "social entrepreneurs" and political or organizational leaders. These new attitudes, behaviors, and motivations are essential to the preparation of the engineers needed for the Grand Challenges (Miller, 2010). 
INMR

15,1

The vision of Richard Miller has been implemented in practice both at Olin College in Massachusetts and at Insper in Brazil. Students at these institutions seek to define engineering issues based on real and specific needs, taking into account the project behind a product, its manufacturing and the development of the company/business for its commercial operation. All the stages of learning are replete with practical activities, where students unravel the complexities of the technology before delving deeper into the supporting theories. Brazil faces the challenge of extending the experiences at Olin College and Insper to its main engineering schools aiming at producing more motivated, creative and innovative engineers.

\section{Challenges and prospects}

Based on the analysis outlined, the development of engineering is evidently an important requirement for supporting business and economic success in Brazil. Clearly, there is a need to enhance the proportion of $\mathrm{PhD}$ holders and qualified individuals in engineering, with the aim of having a higher number of professionals equipped to operate the business and scientific systems in engineering. In particular, there is a demand for professionals who are able to perform duties in research, development and innovation at companies, bolstering this weak branch of the Brazilian business system. The need to increase the number of $\mathrm{PhD}$ holders in engineering has been highlighted in the National Graduate Qualification Plans. The latest plans (2011-2020) specially highlighted the objective of broadening Brazilian graduate qualifications in technology and engineering. This was defined as one of the greatest challenges with regard to the interplay between academic research and the business world, which is crucial to the development of strategic sectors in the country. Another obvious challenge is that of enhancing the formalization of engineering knowledge generated in the country through quality publications. Planning is also needed to enhance certain engineering fields that are vital to a Brazilian development strategy. The reinforcement of chemical and electrical engineering, for instance, is necessary to support industry. Notably, chemical engineering accounts for 10.2 per cent of Brazil's engineering bibliographic production, while the worldwide proportion is close to 12.4 per cent of all engineering. This type of analysis, though simplified, represents a way to seek balance between interconnected engineering fields, helping the country to understand how it can find its place on the world stage. In further respect to the chemical industry*, chemical products represent the fourth most significant participation in industrial GDP, and the net turnover of the Brazilian chemical industry occupies fifth place at the global level. Nevertheless, the trade deficit for chemical products has increased enormously, from US $\$ 1.5 b n$ in 1991 to US\$32.2bn in 2013, highlighting the need to strengthen national chemical engineering.

The analysis of the roles of engineers at companies and in research should also be a guide to establish priorities in the sector's development. Furthermore, attention needs to be paid to the integration of engineering fields, especially production engineering and the other modalities. Mastery of technologies that enable innovation, for instance, nanotechnology, mechatronics and innovating materials, has triggered almost unlimited transformation in the development of new products and in the addition of features to existing products. Mastery of such technology in the sphere of engineering should be one of the priorities in creating new fields of specialization. Another challenge is the consolidation of the complete engineer-researcher paradigm. The profile of this professional should combine the skills of research and innovation with an entrepreneurial spirit. There is a great opportunity to develop Brazilian business, which depends considerably on this complete professional operating in the sector of business RD\&I. The engineer-researcher should not just publish in 
the best engineering journals but should also be able to monitor the business sector so that they may make valuable contributions to science. Besides, they should seek ways to enable the implantation of their ideas in public or private companies. Thus, they can maintain a continuous learning experience regarding the specific demands and strengthen the virtuous circle of innovation, generating the necessary social impacts for Brazil.

The opportunities for engineers are numerous and should be seized to the maximum. In particular, with respect to the Science without Borders program, engineers were able to gain skills at some of the world's best universities, both at undergraduate and graduate levels and development (professional master's, $\mathrm{PhD}$ and post-doctoral studies). Moreover, this experience was complemented through the completion of research internships at foreign and multinational companies, during students' mobility abroad. With qualified students, such integration brings the experience of these centers to the collaboration between universities and companies in engineering. Moreover, emphasis is to be placed on collaboration with international companies in Brazil, which bring experience and expertise to Brazilian companies, and collaboration with major engineering centers worldwide, in Europe, the US and Asian countries. Certainly, the country must not waste the opportunity to establish academic collaborations in engineering with Brazilian companies or with clusters of Brazilian companies, which, at present, really need innovation to grow more quickly.

Regarding the structuring of the system for RD\&I and the training of human resources in engineering, general targets should include:

- The development of collaboration networks, with the aim of supporting research geared toward subjects concerning the paired sectors, business/technology, which include research into new business models coupled with the development of production systems and of product technologies; the EMBRAPII model follows this line;

- The creation of human resources training programs that face the challenges described in this analysis so as to stimulate collaboration with the business sector; and

- The development of new, small companies, the expertise of which can cater for the demands of larger enterprises; the professional Master's is a very appropriate mechanism for convergence with companies; this modality has been included as an affordable modality by the Science without Borders program.

Finally, one prospect that cannot be ignored is environmental sustainability in the RD\&I activities in engineering. This represents simultaneously a challenge for humanity and a great opportunity for inclusion in global markets, which are increasingly aware of the problems of human resources shortages and global warming. New business models that prioritize the sale of a service to use a product, rather than the commercialization of the physical goods, are revolutionizing the market, as exemplified by UBER and AIRBNB. Such business models are more sustainable and demand a new vision of product and process engineering. The paradigm of environmental sustainability and the tools for life-cycle analysis must, therefore, be present across all the RD\&I activities in engineering, from the conception of the human need for a product to its production and disposal.

\section{Conclusions}

Engineering is a powerful instrument for promoting the social and economic development of nations. Its enhancement is a strategic element to accelerate Brazil's progress. The data analysis shows that emerging nations have invested heavily in the growth of their 
INMR

15,1

engineering. There is a need to continue investing in the development of Brazilian engineering through maintaining academic mobility programs, such as Science without Borders, as well as implementing new teaching methodologies and integrating globally, through the financing of international research projects. The distribution of this investment in the various fields of engineering must be balanced, taking into account national strategies and the technological interrelations between the fields analyzed in this article. Brazil has strong potential for development in the various fields of engineering and must seize this opportunity in the most efficient and timely manner.

\section{Notes}

1. This research, conducted across 36 countries, regarding the difficulty of companies to find qualified workers, ranked Brazil in second place, behind only Japan. This shortage affects jobs for both technicians and engineers.

2. The advances in investment for Brazil in S,T\&I from the year 2000, illustrated in the World Bank table at: http://data.worldbank.org/indicator/GB.XPD.RSDV.GD.ZS?end=2013\&locations=BR\& start $=2000 \&$ view $=$ chart

3. Geocapes. available at: http://geocapes.capes.gov.br/geocapesds/\# (accessed February 2017).

4. The Conference Board. Corporate Sustainability in Brazil available at: www.conference-board. org/publications/publicationdetail.cfm?publicationid=2763 (accessed 10 October 2014).

5. In accordance with a survey by the NSF (Science and Engineering Indicators, 2012), in the USA, around 4 per cent of all undergraduate diplomas granted are in the field of engineering (2008); in Asian countries, this indicator is 19 per cent, reaching 31 per cent in China. Compared with the confirmed figure of 6 per cent in Brazil, the figures show Brazil's weakness concerning this indicator. Science and Engineering Indicators (2012) Digest. National Science Foundation. Jan., 2012.

6. The World Bank Development Indicators.

7. It is worth highlighting that China occupies first place with regard to participation in publications on engineering, even if its production does not account for Macau, Taiwan and Hong Kong, as per Table III. Taking into consideration only the production of continental China, the number of publications falls to 106,397, though it is still greater than the USA's.

\section{References}

De Meis, L., Arruda, A.P. and Guimarães, J.A. (2007), "The impact of science in Brazil”, IUBMB Life, Vol. 59 No. 4-5, pp. 227-234, doi: 10.1080/15216540701258140 pmid: 17505957.

De Negri, F. and Cavalcante, L.R. (2013), Evolução Recente dos Indicadores de Produtividade no Brasil. Radar: tecnologia, produção e comércio exterior/Instituto de Pesquisa Econômica Aplicada. Diretoria de Estudos e Politicas Setoriais, de Inovação, Regulação e Infraestrutura. - n. 28 (ago. 2013), Ipea, Brasília, Disponível em: www.ipea.gov.br/portal/images/stories/PDFs/radar/ 130911radar28.pdf (accessed 20 September 2014).

Global R\&D Funding Forecast (2017), R\&D Magazine, Winter 2017, available at: www.rdmag.com (accessed 20 May 2017).

Miller, R.K. (2010), "From the Ground up Rethinking Engineering Education in the 21st Century", Proceedings of 2010, Simpósio em Engenharia e Educação Liberal, June 2010, available at: www. olin.edu/about_olin/pdfs/Union\%20College_From\%20the\%20Group\%20Up.pdf (accessed 7 February 2014).

Narim, F., Hamilton, K.S. and Olivastro, D. (1997), "The increase linkage between US technology and public science”, Research Policy, Vol. 26, pp. 317-330. 
Powell, W., White, D., Koput, K. and Owen-Smith, J. (2005), "The life sciences network dynamics and field evolution: the growth of interorganizational collaboration in the life sciences", American Journal of Sociology, Vol. 110 No. 4, pp. 1132-1205.

Science and Engineering Indicators (2012), Digest, National Science Foundation, January 2012.

Engineering and development

Ukon, M., Bezerra, J., Cheng, S., Aguiar, M., Xavier, A. and Le Corre, J. (2013), Confronting the Productivity Challenge, The Boston Consulting Group, BCG, p. 9, available at: www. bcgperspectives.com/Images/Brazil_Confronting_the_Productivity_Challenge_Jan_2013_tcm80126015.pdf (accessed 15 September 2014).

Zanotto, H. and Guimarães, J. (2016), "Unbalanced international collaboration affects adversely the usefulness of countries' scientific output as well as their technological and social impact", Scientometrics, Vol. 109 No. 3, pp. 1789-1814.

\section{Further reading}

Agopyan, V. and Oliveira, J.F.G. (2005), Mestrado Profissional em Engenharia: Uma Oportunidade Para Incrementar a Inovação Colaborativa entre Universidades e os Setores de Produção no Brasil, RBPG, Revista Brasileira de Pós-Graduação, Vol. 2, pp. 79-89.

Brasil (2012), Presidência da República, Secretaria de Assuntos Estratégicos, Desigualdade, Heterogeneidade e Diversidade, Revista.

Guimarães, J.A., Oliveira, J.F. and Prata, A.T. (2007), Engenharia e Desenvolvimento no Brasil. Desafios $e$ Perspectivas, Parcerias Estratégicas/CGEE (Dezembro 2007), available at: seer.cgee.org.br/ index.php/parcerias_estrategicas/article/viewFile/307/301 (accessed 15 September 2016).

Tseng, M.M. (2003), “Industry development perspectives: Global Distribution of World Market”, CIRP 53rd General Assembly, Montreal.

Vozes da Classe Média - Caderno 2 (2012), Brasília, SAE, 2012, available at: www.sae.gov.br/site/wpcontent/ciclodepalestras/livro.php?id=121204180855-51e2317d73f748b48c1586288e1dd27c\& name $=$ Vozes $\% 20 \mathrm{da} \% 20$ Classe $\% 20$ Media $\% 20$ Segundo $\% 20$ Caderno (accessed 20 September 2014).

\section{Corresponding author}

Luís Grochocki can be contacted at: grochocki@stanford.edu

For instructions on how to order reprints of this article, please visit our website: 